\title{
Situation of Colicin Receptors in Surface Layers of Bacterial Cells
}

\author{
By J. ŠMARDA AND U. TAUBENECK \\ Department of General Biology, Faculty of Medicine, Purkyně University, Brno, \\ Czechoslovakia, and Institute for Microbiology and Experimental Therapy \\ of the German Academy of Sciences, Jena, German Democratic Republic
}

(Accepted for publication I December 1967)

\begin{abstract}
SUMMARY
The susceptibilities to a series of colicins of Escherichia coli B, two Proteus mirabilis strains and their respective stable L-forms were compared. Certain stable L-forms are known to be completely devoid of their cell walls and consequently are completely phage-resistant. Nevertheless, such L-forms show the same or even higher degrees of susceptibility to colicins than do their parent bacteria; they also display exactly the same specific patterns of susceptibilities as do the corresponding normal bacillary forms. Colicins may become adsorbed directly to the cytoplasmic membranes of L-forms. The attachment of a colicin molecule to an adsorption site localized in the bacterial cell wall therefore cannot be regarded as a compulsory initial step leading to the killing of the cell (and the specificity of the interaction between colicins and bacterial cells cannot be determined by cell-wall receptors). Adsorption of colicins to $P$. mirabilis (normal and L-forms) is not possible after killing them with formaldehyde. The time of rescue by trypsin of cells which have adsorbed colicin is decreased to zero with L-forms. Obviously, the 'lethal' adsorption of colicins is to receptors in the cytoplasmic membrane.
\end{abstract}

\section{INTRODUCTION}

Both bacteriophages and colicins have been thought to attach to a bacterial cell in similar or even identical ways; namely, by means of receptor sites localized in the outer plastic layer of the cell wall. It is possible to demonstrate unequivocally that the first step in the infection of a sensitive bacterium by a phage particle is always its irreversible adsorption to a specific receptor site in the cell wall. Consequently, a bacterium sensitive to a certain phage will become resistant through the loss of its phage receptors. This may be shown experimentally by comparing the susceptibilities of lysozyme-induced protoplasts of Gram-positive bacteria and of penicillin-induced stable L-forms of Gram-negative bacteria with the corresponding bacillary forms. (P1. I, fig. I). Both protoplasts and certain stable L-forms completely lack cell walls (Pl. I, fig. 3): consequently, they do not adsorb phages and hence are absolutely phageresistant (Martin, 1964; McQuillen, 1960; Taubeneck, I961, 1962, 1963). On the other hand, spheroplasts of Gram-negative bacteria, which show an incomplete biosynthesis of the murein layer, nevertheless retain the essential components of their cell walls (Pl. I, fig. 2) and hence remain sensitive to bacteriophages (Böhme \& Taubeneck, 1958; Hofschneider, 1960).

Whilst the localization and function of phage receptors in the surface layers of the

Vol. 52, No. I, was issued 25 June 1968 
bacterial cell is relatively well established, this is by no means true for the receptors of colicins. Until now the theory of colicin-fixing receptors formulated by Fredericq (I949) has been generally accepted. According to this theory, the lethal unit of a colicin becomes fixed to the sensitive cell by means of a specific receptor in its cell wall. This adsorption, irreversible under the usual conditions, is supposed to represent the first essential step in the interaction of any colicin with a sensitive cell, irrespective of its specific biochemical effect (Nomura, 1964). Every type of colicin is bound to a different receptor. Those cells which do not possess receptors for a given colicin, or receptors which have mutated to an ineffective state, are resistant to the colicin in question. The capacity of the wall to bind a colicin would thus primarily determine the sensitivity of the cell to it. This theory therefore envisages colicin receptors as being completely analogous to phage receptors, and, according to Fredericq (I949), certain phages may even share common receptors with certain colicins. This latter finding, however, has recently been seriously questioned by some authors (Reeves, 1965; Šmarda \& Schuhmann, 1967). It has also been found that specific antibodies against the bacteria of one sensitive strain prevented the action of colicin $\mathrm{E} 2$ on this strain, but not on the bacteria of another sensitive strain, although the cellwall receptor antigen should be the same in both cases (Mayr-Harting, 1964). Finally, the kinetics of colicin adsorption is different from that of phages (Fredericq, 1952 $b$ ). Mainly for these reasons we hold that the present concept of colicin receptors is not a complete and definitive one (Šmarda, 1966a).

Our preliminary observations showed that some stable L-forms of Proteus mirabilis, although completely phage-resistant, displayed a remarkable sensitivity to certain colicins (U. Taubeneck, unpublished results). We therefore made further experiments to determine whether the adsorption of different types of colicins to bacterial cell walls is in fact a pre-requisite for their action. For these experiments we chose the stable L-form of the $P$. mirabilis strain D 52, a strain whose chemical composition has been most thoroughly analysed. Thus, Martin (1964) found no trace of diaminopimelic acid (also Weibull et al. 1967), muramic acid, neutral sugars or lipids; i.e. of any typical bacterial cell-wall components. It was concluded, therefore, that the cells of this particular stable L-form represent true protoplasts. This is in agreement with the finding (Taubeneck, 196I) that this stable L-form is not capable of adsorbing any phages which infect the parent rod form. In particular, phage BF 23, which supposedly shares a common receptor with colicins of the $E$ group, has no effect on the L-form.

In the work reported here, ultrathin sections of the D 52 stable L-form of Proteus mirabilis showed no organized material outside the cytoplasmic membrane in the electron microscope (P1. I, fig. 3), a result which has also been reported by Weibull (1965). These experiments also included observations on a stable L-form of Escherichia coli B which had recently been isolated and which had been shown to be resistant to all phages active on $E$. coli B rods (Taubeneck \& Schuhmann, I966). (Unfortunately we had no stable L-form of a colicin-resistant mutant strain at our disposal.)

\section{METHODS}

Bacterial strains. The colicinogenic strains used are listed in Table $\mathrm{I}$. The indicator strains were: Escherichia coli $\phi, E$. coli B and a stable L-form of $E$. coli B, E. coli I7, Proteus mirabilis VI, $P$. mirabilis D 52 and stable L-forms of $P$. mirabilis VI and D 52. 
Nutrient media and cultivation. Broth cultures (beef extract with I \% peptone and $0.5 \% \mathrm{NaCl}, \mathrm{pH} 7.8$ ) were grown in $500 \mathrm{ml}$. flasks. $50 \mathrm{ml}$. broth were inoculated with $0.5 \mathrm{ml}$. of an overnight broth culture of the bacteria or with $5 \mathrm{ml}$. of a stable L-form culture respectively and incubated at $37^{\circ}$ on a rotary shaker overnight. In contrast to the stable $P$. mirabilis L-forms, the stable L-form of $E$. coli B could be grown on solid media only. Broth suspensions were prepared by mechanical dispersion of surface growth from agar cultures. For double-layer plates, media with $1.5 \%$ or $2 \%$ agar were used as base layers, with $0.7 \%$ or $0.9 \%$ as top layers. The P. mirabilis L-forms were cultivated with the addition of $10 \%(\mathrm{v} / \mathrm{v})$ horse serum, the $E$. coli B L-forms with I0 $\%(\mathrm{v} / \mathrm{v})$ serum and $3.5 \%$ sucrose. Plates inoculated with a suspension of this latter L-form had to be incubated for 6-7 days.

Table I. Colicinogenic strains of different enterobacteria used and the colicins produced by them

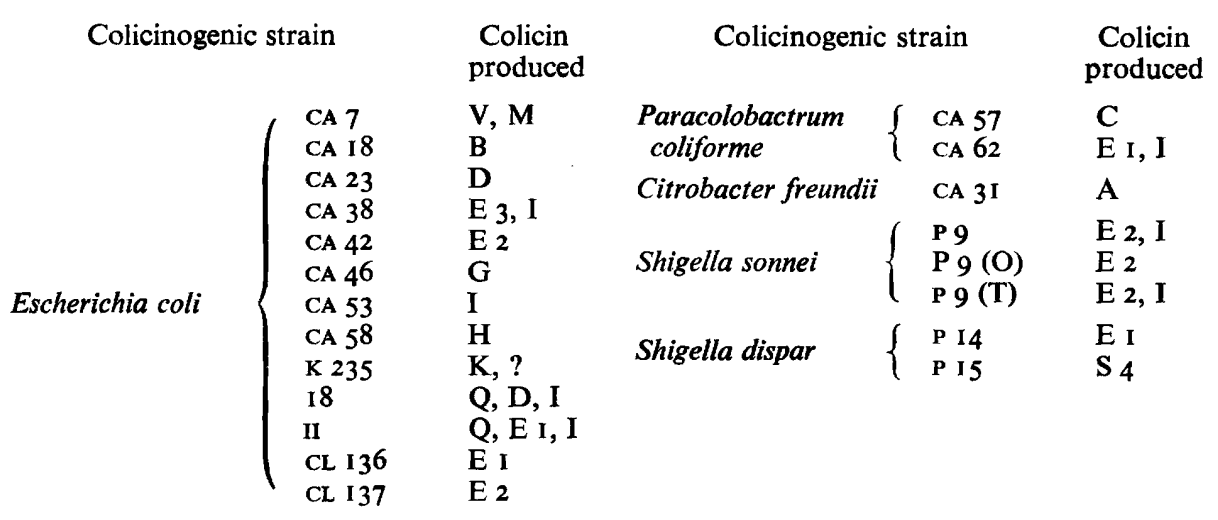

Colicins. As colicins we used filtrates (membrane filters 'Synthesia' HUFS-pore diameter $0.3-0.5 \mu$ ) of overnight broth cultures of colicinogenic strains. The strain specificity of the bactericidal effects was tested on 50 strains of Escherichia coli and 20 strains of Proteus vulgaris and P. mirabilis; the filtrate of P $9(\mathrm{O})$ inhibited $3 \mathrm{I}$ strains and that of $\mathrm{CA} 46$ inhibited 27. The complete abolition of the action by trypsin indicated that the antibacterial activity of the filtrates was exclusively due to colicins.

Most experiments were made with colicins E 2 (from Shigella sonnei P $9(\mathrm{O})$ ) and $\mathrm{G}$ (from Escherichia coli CA 46). As indicator for colicin E 2 we generally used E. coli $\phi$, for colicin G a stable L-form of $P$. mirabilis D 52, these strains being most strongly affected by the respective colicins. The molecular weight of colicin $E 2$ is 60,000 (Helinski, quoted by Maeda \& Nomura, 1966), the figures for colicin $\mathrm{G}$ being probably lower than 50,000 (Geuther, personal communication). Colicin E 2 interferes with DNA synthesis and induces the breakdown of DNA (Nomura, 1964) and of ribosomal RNA (Nose, Mizuno \& Ozeki, 1966). Nothing is known about the mechanism of action of colicin $\mathrm{G}$, but it is not accompanied by any provable change of the submicroscopic structure of the cytoplasmic membrane (Gumpert \& Šmarda, I968).

Demonstration of the action of colicins on agar. In the first place we tested for the presence of colicins by a drop method with agar double layers with indicator bacteria embedded in the soft top layer. For quantitative experiments a more sensitive method 
was used, namely the formation of inhibition zones round chloroform-killed macrocolonies of colicinogenic bacteria (Fredericq, 1957). Despite its much higher sensitivity, the results obtained with this method need not necessarily agree with those obtained by estimation of the killing action of the same colicins in liquid medium.

Colicin titration. To estimate the titre approximately, we looked for the highest dilution causing the last, weak, but still visible action; as a titre of colicin in 'arbitrary units' (Jacob, Siminovitch \& Wollman, 1952) the inverse value of this dilution was evaluated.

In all experiments where an accurate titration of colicins $\mathbf{E} 2$ and $\mathrm{G}$ was necessary, the punch-hole method (van Horn, I96I) was used. Its principle lies in a comparison of the width of inhibition zones formed by diffusing colicin solutions of various standard concentrations, with those of the unknown samples. The absolute titre values of a standard solution were ascertained from the number of the surviving indicator bacteria ( $E$. coli $\phi$ rods for colicin $\mathrm{E} 2$ and $P$. mirabilis $\mathrm{D} 52 \mathrm{~L}$-form for colicin G) in broth suspensions (Mayr-Harting, 1964). In both cases we could confirm that $\mathrm{I}$ arbitrary unit corresponded roughly to $5 \times 10^{7}$ lethal units (1.u.).

\section{RESULTS}

Action of colicins on normal forms and stable L-forms of Escherichia coli $B$, Proteus mirabilis D 52 and P. mirabilis VI

Individual colicins reveal different activity spectra, but primarily only strains of the genera Escherichia and Shigella are inhibited. Proteus species are supposed to be resistant to colicins with the exception of colicin H (Fredericq, I948). In fact, $58 \%$ of the strains of $P$. morganii tested were sensitive to colicin H (Vieu, I960). Preliminary experiments showed, however, that some strains of $P$. mirabilis were sensitive to several other colicins (Šmarda, Taubeneck \& Schuhmann, I966). Thus it became possible to compare the action of all colicinogenic strains used not only on the normal rod form and stable L-form of $E$. coli B, but also on normal rods and stable L-forms of $P$. mirabilis vI and D 52. All colicins were tested simultaneously on the classical indicator strain $E$. coli $\phi$. In the sensitivity tests Fredericq's ( 1957$)$ method was used primarily. Top layers were inoculated with $\mathrm{I} \times 10^{8}$ to $2 \times 10^{9}$ living normal forms, or $7 \times 10^{8}$ to $3.5 \times 10^{9} P$. mirabilis L-forms, the concentration of the $E$. coli B L-form being lower.

The results with 16 well-known colicinogenic strains out of those $2 \mathrm{I}$ tested are given in Table 2.

Summing the results, we find that all 2 I colicins tested acted on Escherichia coli $\phi$. $E$. coli B was not affected by the following colicins of group E, E I (of CL I 36 and II), E 2 (of P 9 and CL 137 ), colicin M, and probably E 3. On the other hand, Proteus mirabilis VI and D 52 were affected by colicins B, D, E I (of P I4 and CA 62), E 2 (of $P$ 9), $G$ and $H$. All the stable L-forms used are qualitatively as sensitive (or resistant) to colicins as are the corresponding rod forms. But, with the exception of colicin B, the L-forms of $P$. mirabilis were more sensitive to colicins than the rods. With colicin B no difference was observed. The stable L-forms of $\boldsymbol{P}$. mirabilis were even more sensitive to colicins $\mathrm{E} I$ ( $\mathrm{CA} 62$ ), $\mathrm{G}$ and $\mathrm{H}$ than the classical indicator, $E$. coli $\phi$. The stable $E$. coli в L-form was, in several cases, also more sensitive than were $E$. coli B rods. 
The time course of the action of colicins $E 2$ and $G$ on the stable

L-form of Proteus mirabilis $D 52$

The L-forms from an overnight broth culture of Proteus mirabilis D 52 were resuspended in fresh broth at $1 \cdot 7 \times 10^{10}$ to $1.96 \times 10^{10}$ colony-formers $/ \mathrm{ml}$. To ensure an excess of colicin, E 2 at $4.26 \times \mathrm{IO}^{11} \mathrm{l} \mathrm{u}$. $/ \mathrm{ml}$. and colicin $\mathrm{G}$ at $2.28 \times 10^{10} 1 . \mathrm{u}$. $/ \mathrm{ml}$. were used. The suspensions of the stable $\mathrm{L}$-form and solutions of the colicins were mixed $\mathrm{I}+\mathrm{I}(\mathrm{v} / \mathrm{v})$ and the mixtures incubated at $37^{\circ}$. At appropriate intervals, samples were

Table 2. Action of 13 colicinogenic strains on Escherichia coli $\phi$ and $B$, and Proteus mirabilis $D 52$, rod form and stable $L$-form

Diameter of the inhibition zone: o mm., - ; $1-5 \mathrm{~mm} .,+$; 6-15 mm., ++ ; > I5 mm., +++ .

\begin{tabular}{|c|c|c|c|c|c|}
\hline \multirow[b]{3}{*}{$\begin{array}{l}\text { Colicinogenic strains } \\
\text { (colicins) }\end{array}$} & \multicolumn{5}{|c|}{ Indicator strains } \\
\hline & \multicolumn{3}{|c|}{ E. coli } & \multicolumn{2}{|c|}{ P. mirabilis D 52} \\
\hline & $\phi$ & B & $\begin{array}{l}\text { Stable L- } \\
\text { form of B }\end{array}$ & Rod form & $\begin{array}{c}\text { Stable } \\
\text { L-form }\end{array}$ \\
\hline CA $3 I$ (A) & + & N.T.* & N.T. & - & - \\
\hline CA I8 (B) & $+t$ & ++ & ++ & $+t$ & ++ \\
\hline CA 57 (C) & ++ & N.T. & N.T. & - & - \\
\hline CA 23 (D) & ++ & ++ & ++ & $+t$ & +++ \\
\hline P I4 (E I) & ++ & + & ++ & ++ & +++ \\
\hline $\mathrm{CL} 136$ (E l) & ++ & - & - & - & - \\
\hline $\mathrm{CA} 42$ (E 2) & ++ & $+\dagger$ & $+++\dagger$ & - & - \\
\hline P 9 (o) (E 2) & ++ & - & - & +++ & +++ \\
\hline CL 137 (E 2) & $+t$ & - & - & - & - \\
\hline $\mathrm{CA}_{38}\left(\mathrm{E}_{3}+\mathrm{I}\right)$ & ++ & + & +++ & - & - \\
\hline CA $46(G)$ & ++ & ++ & +++ & +++ & $+++\ddagger$ \\
\hline CA $58(\mathrm{H})$ & ++ & ++ & +++ & ++ & $+++\ddagger$ \\
\hline CA 53 (I) & ++ & ++ & ++ & - & - \\
\hline K $235(\mathrm{~K}+?)$ & ++ & + & ++ & - & - \\
\hline P I5 (S 4$)$ & + & N.T. & N.T. & - & - \\
\hline $\mathrm{CA} 7(\mathrm{~V}+\mathrm{M})$ & ++ & ++ & ++ & - & - \\
\hline
\end{tabular}

taken for counting the L-form colonies and, after rapid removal of the organisms by membrane ultrafiltration, for assay of free colicin by the punch-hole method. The results are given in Fig. I and 2. There was a marked difference in the effect of the two colicins.

Immediately after mixing with colicin $\mathrm{E} 2$ the number of L-form colonies decreased by about tenfold. After $10 \mathrm{~min}$. the surviving elements started to divide again very slowly, although about $63 \%$ of free unadsorbed colicin remained in the mixture. A very similar course was shown by the titre of free colicin E 2. After an immediate decrease it increased again markedly during the first $10 \mathrm{~min}$.

The action of colicin $G$ was much stronger and more prolonged. This agent decreased the number of living L-forms by 4 orders of magnitude during $40 \mathrm{~min}$. Also, adsorption was accomplished immediately after mixing. Afterwards the titration curve showed only an insignificant tendency to increase. 
Adsorption and action of colicins $E 2$ and $G$ on the rods of Escherichia coli $\phi$ and $I 7$ and on the rods and stable L-forms of Proteus mirabilis D 52

The method was standardized according to Mayr-Harting (1964). Colicin suspension was mixed I $+\mathrm{I}(\mathrm{v} / \mathrm{v})$ with a suspension of bacteria in broth, incubated for $60 \mathrm{~min}$. at $37^{\circ}$ and then for at least $90 \mathrm{~min}$. at $4^{\circ}$. Then the counting of survivors and the assay of the remaining free colicin by the punch-hole method were done, typical results are presented in Table 3.

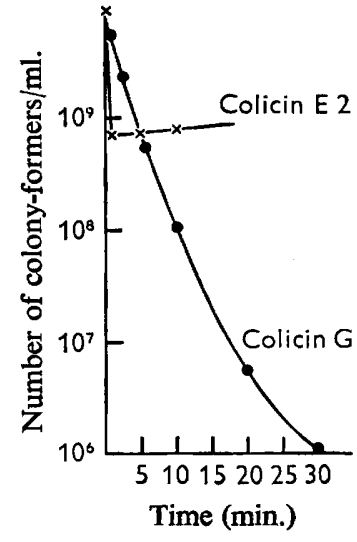

Fig. I

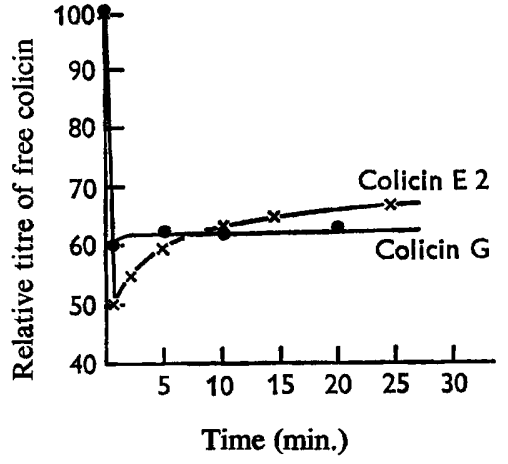

Fig. 2

Fig. I. Survival of stable L-forms of Proteus mirabilis D 52 in suspensions containing colicins $\mathrm{E} 2$ or G. For techniques, see the text.

Fig. 2. Relative titre of free colicins E 2 and $\mathrm{G}$ in suspensions of stable L-forms of Proteus mirabilis $\mathrm{D} 52$. For techniques see the text.

Table 3. Adsorption and action of colicins $E 2$ and $G$ to living bacteria

\begin{tabular}{|c|c|c|c|c|c|}
\hline Colicin & Bacteria & $\begin{array}{c}\text { Original no. } \\
\text { of colony- } \\
\text { formers/ml. } \\
\text { of suspension } \\
\text { with colicin }\end{array}$ & $\begin{array}{l}\text { No. of colony- } \\
\text { formers } \\
\text { killed/ml. }\end{array}$ & $\begin{array}{l}\text { Original coli- } \\
\text { cin titre/ml. } \\
\text { of suspen- } \\
\text { sion with } \\
\text { bacteria (l.u.) }\end{array}$ & $\begin{array}{l}\text { Decrease of } \\
\text { colicin } \\
\text { titre }(\%)\end{array}$ \\
\hline \multirow[t]{3}{*}{ E 2} & Escherichia coli $\phi$ & $3.58 \times 10^{9}$ & $3.54 \times 10^{9}$ & $1 \cdot 34 \times 10^{10}$ & 100 \\
\hline & $\begin{array}{l}\text { E. coli } 17 \\
\text { Proteus mirabilis }\end{array}$ & $\begin{array}{l}6.62 \times 10^{9} \\
5.54 \times 10^{9}\end{array}$ & $\begin{array}{l}0 \\
0\end{array}$ & $\begin{array}{l}1 \cdot 34 \times 10^{10} \\
1 \cdot 34 \times 10^{10}\end{array}$ & $\begin{array}{l}3 \\
8\end{array}$ \\
\hline & $\begin{array}{l}\text { D } 52 \text { rod form } \\
P . \text { mirabilis D } 52 \\
\text { stable L-form }\end{array}$ & $4.53 \times 10^{9}$ & $1 \cdot 37 \times 10^{9}$ & $1 \cdot 34 \times 10^{10}$ & I 6 \\
\hline \multirow[t]{5}{*}{ G } & E. coli $\phi$ & $9.35 \times 10^{9}$ & 0 & $1 \cdot 14 \times 10^{10}$ & I 3 \\
\hline & E. coli 17 & $5.17 \times 10^{9}$ & 0 & $1 \cdot 14 \times 10^{10}$ & 4 \\
\hline & $\begin{array}{l}P \text {. mirabilis D } 52 \\
\text { rod form (in culti- } \\
\text { vation medium) }\end{array}$ & $6.65 \times 10^{9}$ & 0 & $1.14 \times 10^{10}$ & 100 \\
\hline & $\begin{array}{l}P . \text { mirabilis D } 52 \\
\text { rod form (in } \\
\text { fresh medium) }\end{array}$ & $8.40 \times 10^{8}$ & $1 \cdot 20 \times 10^{9}$ & $I \cdot 14 \times 10^{10}$ & 13 \\
\hline & $\begin{array}{l}\text { P. mirabilis D } 52 \\
\text { stable L-form }\end{array}$ & $5.80 \times 10^{9}$ & $5.79 \times 10^{9}$ & $1 \cdot 14 \times 10^{10}$ & 42 \\
\hline
\end{tabular}

Colicin E 2 acted vigorously on Eschericha coli $\phi$, and $3.58 \times 10^{9}$ bacteria $/ \mathrm{ml}$. adsorb $100 \%$ of this colicin, i.e. $\mathrm{I} \cdot 34 \times 10^{10} \mathrm{l} . \mathrm{u}$./ml. The adsorption capacity was probably still not saturated by this amount. It was confirmed that $E$. coli 17 was resistant to 
colicins $\mathrm{E} 2$ and $\mathrm{G}$ and that it did not adsorb them significantly. The action of colicin E 2 on the rods of Proteus mirabilis D 52 and of colicin G on the rods of E. coli $\phi$ was so weak that, in the heavy suspensions used, no killing was detected. In this case, too, the decrease of the titres of these colicins was only about $10 \%$.

Colicin G did not affect Proteus mirabilis D 52 rods when applied in the original culture medium, but it vanished completely from the solution. After resuspending the bacteria in fresh broth, however, some bacteria were killed and only about $13 \%$ of the colicin was adsorbed. This paradox may be explained by the finding of a specific extracellular inhibitor for colicin $\mathrm{G}$ which is produced and excreted in broth cultures of $P$. mirabilis D 52 (Šmarda, 1966b). The stable L-form of $P$. mirabilis D 52 was substantially more sensitive to both colicins than the rod form and its adsorption capacity was higher; the number of elements killed depended directly on the amount of colicin adsorbed. The lethal effect of colicin $\mathrm{G}$ on the $\mathbf{L}$-form of $P$. mirabilis was extremely strong, although less than I l.u./organism was adsorbed. The data suggest that colicin $\mathrm{G}$ molecules can possibly be released from the inactivated L-forms and are then able to kill new ones.

Table 4. Adsorption of colicins $E 2$ and $G$ to dead bacteria

\begin{tabular}{|c|c|c|c|c|c|}
\hline Colicin & Bacteria & $\begin{array}{c}\text { No. of orga- } \\
\text { nisms/ml. of } \\
\text { suspension } \\
\text { with colicin }\end{array}$ & $\begin{array}{l}\text { No. of orga- } \\
\text { nisms surviv- } \\
\text { ing form- } \\
\text { aldehyde } / \mathrm{ml} \text {. }\end{array}$ & $\begin{array}{l}\text { Original coli- } \\
\text { cin titre/ ml. of } \\
\text { suspension with } \\
\text { bacteria (l.u.) }\end{array}$ & $\begin{array}{c}\text { Decrease of } \\
\text { colicin titre }(\%)\end{array}$ \\
\hline \multirow[t]{2}{*}{$\mathrm{E}_{2}$} & $\begin{array}{l}\text { Escherichia coli } \phi \\
\text { Proteus mirabilis } \\
\text { D } 52 \text { rod form }\end{array}$ & $\begin{array}{l}1.85 \times 10^{9} \\
1.84 \times 10^{10}\end{array}$ & $\begin{array}{l}0 \\
0\end{array}$ & $\begin{array}{l}4.26 \times 10^{10} \\
4.26 \times 10^{10}\end{array}$ & $\begin{array}{r}100 \\
0\end{array}$ \\
\hline & $\begin{array}{l}\text { P. mirabilis D } 52 \\
\text { stable L-form }\end{array}$ & $3.72 \times 10^{8}$ & $10^{2}$ & $4.26 \times 10^{10}$ & 0 \\
\hline \multirow[t]{2}{*}{ G } & $\begin{array}{l}\text { E. coli } \phi \\
P . \text { mirabilis D } 52 \\
\text { rod form }\end{array}$ & $\begin{array}{l}9.35 \times 10^{9} \\
8.40 \times 10^{9}\end{array}$ & $\begin{array}{c}10^{3} \\
0\end{array}$ & $\begin{array}{l}I \cdot 14 \times 10^{10} \\
1 \cdot 14 \times 10^{10}\end{array}$ & $\begin{array}{r}13 \\
0\end{array}$ \\
\hline & $\begin{array}{l}\text { P. mirabilis D } 52 \\
\text { stable L-form }\end{array}$ & $2.60 \times 10^{9}$ & ० & $I \cdot 14 \times 10^{10}$ & 4 \\
\hline
\end{tabular}

Adsorption of colicins $E 2$ and $G$ to rods of Escherichia coli $\phi$ and rods and stable L-forms of Proteus mirabilis D 52, previously killed with formaldehyde

If the adsorption of colicins to the stable L-form of Proteus mirabilis D 52 is really reversible, this would be in complete contrast to colicin adsorption by rods of Escherichia coli $\phi$. To examine this difference, we made a series of adsorption experiments with killed organisms. The same bacterial suspensions (only the resistant strain, E. coli 17 was omitted) and stable L-form suspensions and the same colicin G solution were used as in the experiments with living bacteria and their L-forms. The titre of colicin E 2 was $4.26 \times 10^{10} 1 . u$. $/ \mathrm{ml}$. According to Mayr-Harting (1964), $0.2 \mathrm{ml}$. of $3 \%$ $(\mathrm{w} / \mathrm{v})$ formaldehyde was added to $3 \mathrm{ml}$. of each suspension, stirred, and incubated for I $\mathrm{hr}$ at $37^{\circ}$. Then the bacteria were spun down, once washed with broth, resuspended in $3 \mathrm{ml}$. fresh broth and used for adsorption under the same conditions as previously stated. The results are given in Table 4 .

The comparison with the results of adsorption to living bacteria (Table 3 ) shows the difference between the reaction of the rods of Escherichia coli $\phi$ and of Proteus mirabilis D 52. While the degree of adsorption of colicins E 2 (as already stated by Mayr-Harting, 1964) and $\mathrm{G}$ to rods of $E$. coli $\phi$ was not changed by killing the bacteria 
with formaldehyde, it was notably decreased in the case of normal forms and especially of stable L-forms of $\boldsymbol{P}$. mirabilis D 52; here the capacity to bind colicin E 2 decreased from $16 \%$ to zero, and from $42 \%$ to $4 \%$ in the case of colicin G.

\section{Attempts to rescue stable L-forms of Proteus mirabilis $D 52$ by trypsin after the attachment of colicin $E 2$ and $G$}

Trypsin (0.15-0.5\% (w/v) solution) was added to a mixture of Proteus mirabilis D 52 L-forms and colicins $\mathrm{E} 2$ or $\mathrm{G}$ at different times. The activity of trypsin towards the colicins was determined separately before each experiment. Any errors arising from multiplication of organisms during the incubation with trypsin were excluded by

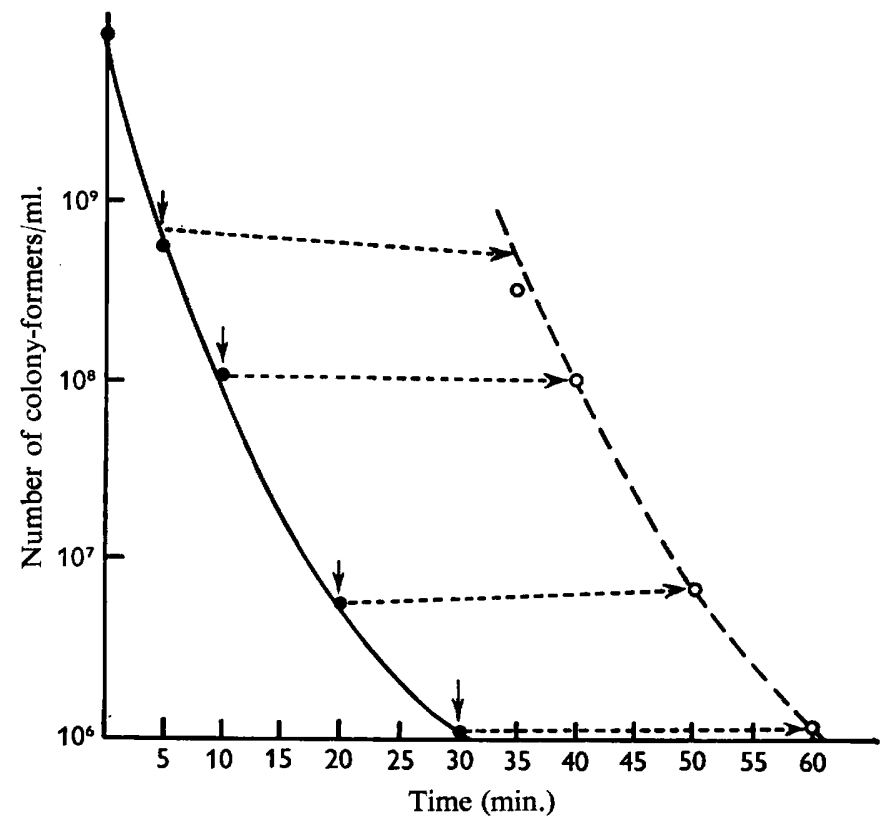

Fig. 3. Number of colony-formers in Proteus mirabilis D 52 L-form broth suspension with colicin $\mathrm{G}$ at $37^{\circ}$. At zero time, L-form suspension was mixed with colicin G. After 5, I0, 20 and $30 \mathrm{~min}$. the survival count was made by plating (full circles); at the same times warmed trypsin solution was added to each sample (full arrows). The samples were incubated at $37^{\circ}$ for a further $30 \mathrm{~min}$. (dashed arrows) and the number of colony-formers again ascertained in each sample (empty circles) to check whether an increase of the number of survivors occurred after the action of trypsin.

control experiments. The results with colicin $G$ are given in Fig. 3 which shows that there was no reactivation effect of trypsin in the case of the L-forms even after only short exposures to colicin G. Even when trypsin was added immediately after mixing the L-form with colicin E 2, no reactivation was observed. Thus, contrary to Escherichia coli rods, the stable L-forms of Proteus mirabilis were no rescued after the attachment of colicins $\mathbf{E} 2$ or G. 


\section{DISCUSSION}

Our results suggest that the bacterial cell wall plays quite different roles in the lethal actions of bacteriophages and colicins, respectively. Phage receptors in the walls of sensitive bacteria mediate a type-specific adsorption of phage particles. The attachment of the phage to the receptor site is necessary for successful infection Iof $_{\text {o }}$ bacterium. Bacteria without cell walls, i.e. protoplasts and stable L-forms of the protoplast type, are therefore not able to adsorb phages and consequently are phageresistant (Taubeneck, I96I, I963; Taubeneck \& Schuhmann, 1966).

Receptor sites for colicins also mediate a strain-specific adsorption. The results of reactivation experiments (Nomura \& Nakamura, 1962; Reynolds \& Reeves, 1963; Šmarda, 1965) suggested that the lethal unit of colicin does not penetrate the cell, but remains attached to its surface. An accurate cytological interpretation of what is meant as 'bacterial surface' in this connexion has not yet been given. Nevertheless, this suggestion has been verified by experiments with radioactive colicins (Maeda \& Nomura, 1966). It is thought (Nomura, 1964) that the primary change at a receptor site on the bacterial surface caused by a colicin is to induce a stimulus which is transferred by a specific (and until now hypothetical) mechanism, presumably through the cell wall and along the cytoplasmic membrane to the killing (biochemical) target. The biochemical changes induced in the organisms attacked by different colicins may differ according to the diverse stimuli induced by the respective substances. There is little doubt that the common seat of the relevant actions is the cytoplasmic membrane (Luria, 1964). The results presented here strongly suggest that adsorption of colicin to an adsorption site in the cell wall is not an essential prerequisite for its killing effect.

This evidence stems mainly from experiments in which the effects of colicin E 2 and G on normal forms of Proteus mirabilis D 52 and Escherichia coli B and on the stable L-forms of these strains were compared. The stable L-forms are resistant to all phages which attack their parent bacteria, and it has been shown by biochemical analysis that, at least in the case of the stable L-form of $P$. mirabilis D 52, no cell-wall components can be detected (Martin, 1964). Preliminary observations on the stable L-form of $E$. coli в have shown that besides its resistance to phages $\mathrm{T}_{\mathrm{I}}-7$, BF 23 and $\lambda$ (Taubeneck \& Schuhmann, I966), this L-form contains only traces of diaminopimelic acid, which certainly come from intermediary metabolism and not from cell-wall murein.

In spite of the fact that they completely lack cell walls, stable L-forms of Proteus mirabilis D 52 and of Escherichia coli B are sensitive to the action of colicins B, D, some $\mathrm{E} \mathrm{I}$ and $\mathrm{E} \mathrm{2,} \mathrm{G} \mathrm{and} \mathrm{H}$. Moreover, there is essentially no qualitative difference between the sensitivity of rods and L-forms. This suggests that colicins may adsorb directly to the cytoplasmic membrane which forms the true surface of our L-forms which was shown experimentally with the L-forms of $P$. mirabilis. Whether they adsorb to the site of action proper, or to any other site from which stimuli are transmitted to the killing or biochemical target, cannot yet be decided. In any case, the connexion of the receptor site in the cytoplasmic membrane and the killing target must be rapid and efficient, at least for colicin $\mathrm{E} 2$.

The specificity of the susceptibilities of the L-forms to all the colicins examined is the same as that of the corresponding normal forms with complete cell walls. Thus, specific adsorption of a colicin to an adsorption site in the cell wall cannot be regarded as the start of interaction between the colicin and the bacterial metabolism, 
at least not the necessary one, and there may be another explanation: the effective 'lethal' colicin receptors are not those localized in the cell wall, but those in the cytoplasmic membrane. Only those lethal units can exert their effect which come through the cell wall to the membrane. This is in complete agreement with the finding of Maeda \& Nomura (I966) that nearly all the radioactivity of ${ }^{14} \mathrm{C}$-labelled colicin E 2 after its adsorption on Escherichia coli w 31 IO, followed by their disruption and differential centrifugation, remained in the fraction containing cell walls and cell membranes.

The cross-resistance to certain colicins and phages has never been proved in $100 \%$ of mutants examined. The cases where it actually exists could be explained, for example, by the assumption of a specific chemical structure in the cell wall necessary for both: binding a certain phage and enabling the passage of a certain colicin to the cytoplasmic membrane.

There is little doubt, however, that considerable amounts of colicin may be adsorbed to cell-wall structures. However, much of the adsorption to cell walls might represent a 'non-lethal binding to sites other than those which we have called effective (lethal) receptors' (quoted from Shannon \& Hedges, 1967). The adsorption of a colicin to a cell wall does not necessarily require the viability of the organism; for example, formaldehyde-killed organisms of Escherichia coli adsorb colicins as well as do living ones, and adsorbed colicin is not released after killing the organism (Fredericq, $1952 a$; Maeda \& Nomura, I966). The adsorption capacity of formaldehyde-killed L-forms is extremely limited, and previously adsorbed colicin is set free again (at least to a certain extent) after the killing action of the colicin itself. Preliminary results suggest that it is also set free again after killing the L-forms with chloroform. The observation that normal Proteus rods also, after having been killed with formaldehyde, do not adsorb colicins cannot yet be explained. Perhaps Proteus mirabilis D 52 rods do not possess cell-wall adsorption sites for colicins $\mathrm{E} 2$ and $\mathrm{G}$, although corresponding cytoplasmic membrane receptors and biochemical targets are present. Further experiments are in progress to determine whether this is really due to the different mode of adsorption of colicins to rods and to stable L-forms or rather to a species difference between $E$. coli and $P$. mirabilis.

According to the view of Holland, Hill \& Bellamy (I966), receptors for colicins of the $\mathrm{E}$ group are situated in the innermost layer of the cell wall, in close proximity to the cytoplasmic membrane. The colicins may, in fact, penetrate the wall of bacterial rods and act in the same way as on the L-forms, i.e. directly on the cytoplasmic membrane. The channels in the lipoprotein and lipopolysaccharide layer of the cell wall which have been shown recently (Bayer \& Anderson, 1965) could be regarded as possible pathways of penetration. In this case, the stable L-forms should be expected to be attacked by the colicins more readily; this has been shown by our experiments.

It is known that colicins adsorbed to the cell wall may be digested by trypsin. When this digestion is performed within a certain time after the adsorption to sensitive organisms, the lethal action of the colicins may be prevented (Nomura \& Nakamura I962; Reynolds \& Reeves, I963; Šmarda, 1965). The time limit within which rescue of inactivated organisms is possible is considerably shortened after adsorption of colicins to spheroplasts (Obdržálek, Šmarda, Čech, \& Adler in preparation) and it becomes zero or almost zero after their adsorption to stable L-forms of Proteus mirabilis D 52. This finding further emphasizes an immediate action of colicins on sensitive organisms if these lack their cell walls. 
In view of the characteristics of colicin $G$ (strain specificity of action, no direct effect on cytoplasmic membrane, etc.) it does not seem probable that it would be a phospholipase, like, for example, megacin A (Ozaki et al. 1966), although it is not directly excluded.

We conclude from our results that the bactericidal effect of colicins generally is not mediated through the fixation of a lethal unit of colicin to a cell-wall receptor (followed by the transmission of an as yet unknown stimulus to a killing/biochemical target presumably in the cytoplasmic membrane). This effect on the killing target is readily achieved by a direct and probably reversible contact of a colicin lethal unit with the cytoplasmic membrane, without any specific mechanism involving irreversible fixation to the cell wall as an essential step. In contrast to cell walls, cytoplasmic membranes of formaldehyde-fixed L-forms are not capable of adsorbing colicins. Thus, sensitivity of the organism to colicins is primarily determined by receptors in the cytoplasmic membrane and not in the wall, of the organism, as is the case with bacteriophages.

We are indebted to Dr Anna Mayr-Harting and Professors P. Fredericq and J. Sedlák and to the Czechoslovak Collection of Micro-organisms for some of the Escherichia coli strains. Dr Edith Schuhmann provided stable L-forms of $E$. coli B. The excellent technical assistance of Mrs Gerda Elske is gratefully acknowledged. Ultrathin cell sections for Pl. I fig. I and 3 were kindly prepared by Dr J. Gumpert, for Pl. I, fig. 2 by Dr Marie Havelková.

\section{REFERENCES}

Bayer, M. E. \& Anderson, T. F. (1965). The surface structure of Escherichia coli. Proc. natn. Acad. Sci., U.S.A. 54, 1592.

BöHmE, H. \& TAUBENECK, U. (1958). Die Wirkung von Bakteriophagen auf Normalform und large bodies von Proteus mirabilis. Naturwissenschaften 45, 296.

FredericQ, P. (1948). Actions antibiotiques réciproques chez les Enterobacteriaceae. Rev. belge Path. Méd. exp. 19, suppl. 4, I.

FredericQ, P. (1949). Sur la résistance croisée entre colicine E et bactériophage II. C. r. Séanc. Soc. Biol. 143, IOI I.

FredericQ, P. (1952a). Action bactéricide de la colicine K. C. r. Séanc. Soc. Biol. 146, I 295.

FredericQ, P. (I952 b). Action bactéricide comparée d'un antibiotique, la colicine K, et du bactériophage T 6. Rev. belge Path. Méd. exp. 22, 167.

FredericQ, P. (1957). Les colicines et leurs relations avec les bactériophages. Schweiz. Z. allg. Path. Bakt. 20, 670.

GUMPerT, J. \& ŠmARDA, J. (1968). Phasenkontrast- und elektronenmikroskopische Untersuchungen zur Wirkung von Colicin $\mathrm{G}$ und $\mathrm{E}_{2}$ auf Zellen einer stabilen L-form von Proteus mirabilis. Zentbl. Bakt. Parasitkde. I. Orig. (in the Press).

HofsCHNEIDER, P. H. (1960). $\mathrm{T}_{1}$ and $\lambda$ phage adsorption on protoplast-like bodies of Escherichia coli. Nature, Lond. r86, 568.

Holland, I. B., Hill, C. \& Bellamy, K. (I966). Studies on the mode of action of colicin E. IX Int. Congr. Microbiol. Abstr. p. 34.

VAN HORN, E. A. (196I). The assay of colicin as a special case of a slowly diffusing substance, and the application of assay methods to the study of colicin production. M.Sc. dissertation, University of Bristol.

JaCob, F., Siminovitch, L. \& Wollman, E. (I952). Sur la biosynthèse d'une colicine et sur son mode d'action. Annls Inst. Pasteur, Paris 83, 295.

LuRIA, S. E. (1964). On the mechanisms of action of colicins. Annls Inst. Pasteur, Paris 107, suppl. p. 67.

MAEDA, A. \& NomURA, M. (1966). Interaction of colicin with bacterial cells. I. Studies with radioactive colicins. J. Bact. 91, 685 . 
MARTIN, H. H. (1964). Composition of the mucopolymer in the cell walls of the unstable and stable L-forms of Proteus mirabilis. J. gen. Microbiol. 36, 441.

MaYr-Harting, A. (1964). The adsorption of colicin. J. Path. Bact. 87, 255.

MCQuillen, K. (1960). Bacterial protoplasts. In The Bacteria. Ed. by I. C. Gunsalus and R. Y. Stanier. Vol. I. New York and London: Academic Press.

NomUra, M. (1964). Mechanism of action of colicins. Proc. natn. Acad. Sci. U.S.A. 52, 1514.

Nomura, M. \& NaKamura, M. (1962). Reversibility of inhibition of nucleic acids and protein synthesis by colicin K. Biochem. biophys. Res. Com. 7, 306.

Nose, K., Mizuno, D. \& OzEkI, H. (1966). Degradation of ribosomal RNA from Escherichia coli by colicin E 2. Biochim. biophys. Acta Ir9, 636.

Ozaki, M., Higashi, Y., Saito, H. O. An, T. \& Amano, T. (1966). Identity of megacin A with phospholipase A. Biken's. J. 9, $20 \mathrm{I}$.

ReEves, P. (1965). The bacteriocins. Bact. Rev. 29, 25.

REYNoLDS, B. L. \& REEves, P. R. (1963). Some observations on the mode of action of colicin F. Biochem. biophys. Res. Com. II, I40.

Shannon, R. \& Hedges, J. A. (1967). Kinetics of lethal adsorption of colicin E 2 by Escherichia coli. J. Bact. 93, $\mathrm{I} 353$.

ŠMARDA, J. (1965). Some problems of the immediate action of colicins on susceptible bacteria. Antimicrob. Ag. Chemother. p. 345.

ŠmardA, J. (1966a). The question of bacterial receptors for colicin. Folia microbiol. Praha. II, 64.

S̆MARDA, J. (1966b). Ein von Proteus mirabilis produzierter inhibitor des colicins. G. Z. allg. Mikrobiol. 6, 339.

Smarda, J. \& Schuhmann, E. (1967). Do certain colicins and bacteriophages share common receptors? Nature, Lond. 213, 614 .

Šmarda, J., Taubeneck, U, \& Schuhmann, E. (1966). The action of colicins on bacterial cells and stable L forms. IX Int. Congr. Microbiol. Abstr. p. 7I.

Taubeneck, U. (1961). Die Phagenresistenz der stabilen L-Form von Proteus mirabilis. $Z$. Naturforsch. 16 $8,849$.

TAUBENECK, U. (1962). Untersuchungen über die L-Form von Proteus mirabilis Hauser. II. Entwicklung und Wesen der L-Form. Z. allg. Mikrobiol. 2, 56.

TAUBeneCK, U. (1963). Demonstration of lysogeny in the stable L-forms of Proteus mirabilis. J. Bact. 86, 1265.

TaUbeneck, U. \& Schuhmann, E. (1966). Stabile, penicillininduzierte L-Formen von $E$. coli B. Z. allg. Mikrobiol. 6, 34I.

VIEU, J. F. (1960). Lysogénéité et sensibilité à la colicine $\mathrm{H}$ de Proteus morgani. Annls inst. Pasteur, Paris 98, 769.

Weibuls, C. (1965). Structure of bacterial L forms and their parent bacteria. J. Bact. 90, 1467.

Weibull, C., Bickel, W. D., Haskins, W. T., Milner, K. C. \& Ribi, E. (1967). Chemical, biological, and structural properties of stable Proteus L forms and their parent bacteria. J. Bact. 93, I143.

\section{EXPLANATION OF PLATE}

\section{Plate I}

Fig. I. Ultrathin section of a normal bacillary cell of Proteus mirabilis D 52. Kellenberger fixation. $\times$ I50,000. $C W$, Cell wall; $C M$, cytoplasmic membrane. Note the surface formed by a cell wall and a cytoplasmic membrane.

Fig. 2. Ultrathin section of a penicillin spheroplast of Proteus mirabilis D 52. Kellenberger fixation. $\times$ I $50,000 . S W$, Spheroplast wall; $C M$, cytoplasmic membrane. Note the surface formed by a weakened wall and a cytoplasmic membrane.

Fig. 3. Ultrathin section of a stable L-form of Proteus mirabilis $D$ 52. Kellenberger fixation. $\times 150,000$, $C M$, Cytoplasmic membrane. Note the surface formed by a cytoplasmic membrane 

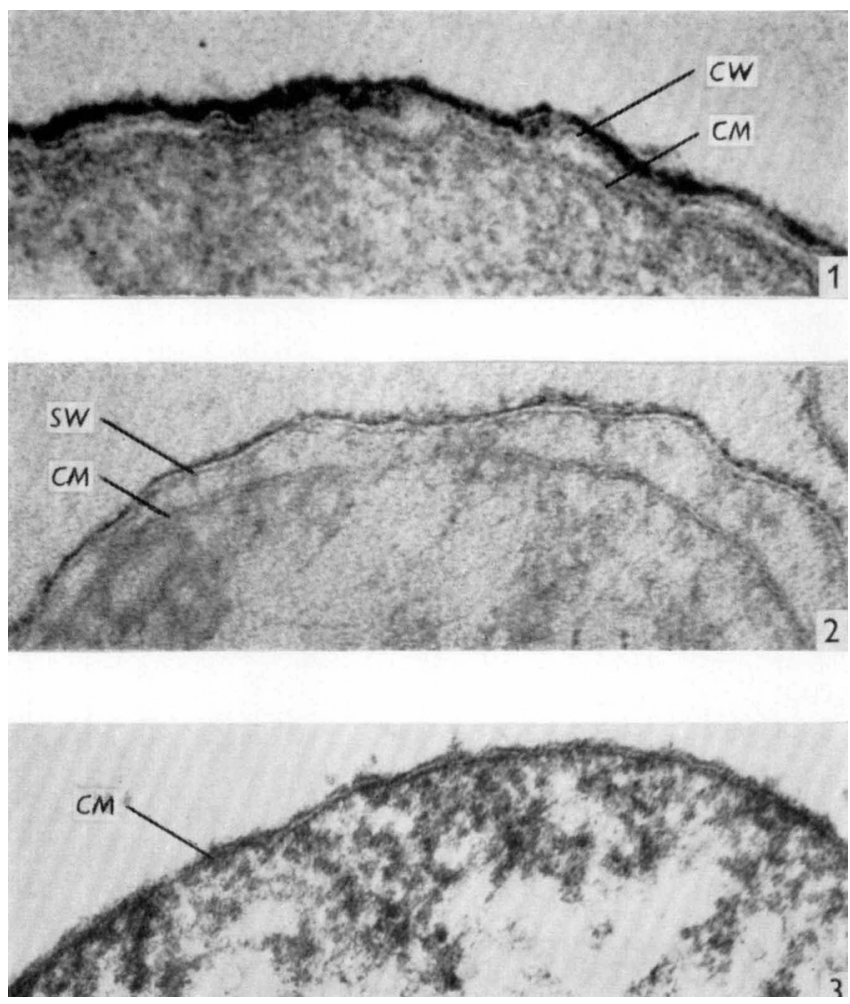